\title{
Highgate Cemetery's Landscape as a Matrix of Imagination
}

\section{Alberto Saviello}

«Death will bring here—not blight and barrenness—but increased and increasing life and beauty.» William Justyne about St James' Cemetery at Highgate, 1865

\section{Introduction}

When entrepreneur, architect and inventor Stephen Geary (1797-1854) founded the London Cemetery Company (LCC) in 1836, the English capital's young cemetery business was already competitive. The British parliament had previously permitted two other joint-stock enterprises to establish burial sites in the outskirts of London at Kensal Green (opened 1833) and at West Norwood (opened 1837).

Although only a small number of the 113 cemetery companies that had been founded between 1820 and 1853 in the United Kingdom followed a strictly profit-oriented model, this was precisely the goal of the LCC, which aimed to flourish «by selling luxury burial services». ${ }^{1}$ An Act of Parliament allowed the company to build three cemeteries north, south and east of the metropolis. ${ }^{2}$ Initially Geary concentrated resources on St James' Cemetery at Highgate, because it was essential for the company's success to make its first project a showpiece. The site itself, of approximately 17 acres at Highgate Village, a neighbourhood of stately mansions approximately four miles from the centre of London, was bought for the relatively modest sum of $£ 3,500$. Critics claimed, however, that the bulk of the capital of $£ 100,000$ that had been invested by the company's shareholders was spent on the landscaping, gardening and architecture of the cemetery. ${ }^{3}$

A particularly promising model for the design of Highgate was the very first European garden cemetery Père Lachaise, which was opened in Paris

1 See Rugg 1997, 105-106; Penny, 1974.

2 Act of Parliament 17 August 1836, (6\&7 William IV, c 136, local); see Curl 1972, 88.

3 See Arnold 2006, 138; Collison 1840, 173 
in 1804. Not only had the Parisian cemetery become a major tourist attraction, the idea of creating a burial ground in a landscape garden setting had already proved to be successful in Great Britain, too: Glasgow Necropolis and Kensal Green Cemetery were flourishing interment sites. ${ }^{4}$ What made Père Lachaise and its imitators so popular? First of all Père Lachaise strongly contrasted with the condition of traditional burial-grounds in urban churchyards. Due to the rapidly rising populations of Europe's major cities the normally rather narrow churchyards had begun to overflow with human remains. Many critics regarded them as places hazardous to health and inappropriate for a permanent and respectful burial. 5 Père Lachaise, by contrast, previously a private park, provided a lofty terrain to promenade upon with a varied landscape and plantation, which afforded a captivating view of the city from its hilltop. Furthermore, when it was opened as a public cemetery, pieces of solemn architecture were added to enhance its respectability as a burial ground. ${ }^{6}$ Most of these features can also be found in British garden cemeteries and Highgate took up this model as well. However, I will suggest another quality that made Highgate special and assured its appeal in the longue durée: St James' at Highgate was designed to stir the visitors' imagination and to open up perspectives on death and life that were new, stimulating, inclusive and yet compliant with social and religious norms.

Cemeteries are generally highly regulated public places that can be considered to be thresholds or liminal spaces where the «communities of the living and the dead come into contact and, in a transcendental sense, where the immanent world meets with the realms of the otherworld. ${ }^{7}$ Cemeteries are locations where a society's collective imaginary relating to cultural and religious concepts of death and afterlife are materially and symbolically expressed, performed and experienced. ${ }^{8}$ Interestingly, Michel Foucault chose the $19^{\text {th }}$ century rural cemetery as an example to outline his concept of a heterotopology.9 According to the French philosopher a het-

4 Only six years after the consecration of Kensal Green, the company's shares had doubled their value. See Curl 1972, 79.

5 On the disastrous conditions of the Victorian graveyards see for example Arnold 2006, 94-122.

6 See Etlin 1984.

7 See also the articles of Carla Danani and Daria Pezzoli-Olgiati in this book.

8 For a more detailed definition of the «cultural imaginarys see the introduction to this book.

9 See Foucault 1984. The Foucaultian model of the heterotopos has also been applied to Highgate Cemetery by Clements 2017. 
erotopos is a kind of utopia enacted in a real place. It is a place separate and different from all common places of a society. It is regarded as sacred and forbidden or, at least, it is regimented by its very own rules. The most important criterion of the heterotopos for the purpose of our discussion is that it not only mirrors the mundane spaces of society but that it can also invert and contest these common places. ${ }^{10}$ Thus, a cemetery reflects the norms and structures of a community but it is also a space of experimentation where a society's self-image can be tested, mingle with the unreal, become distorted and changed.

By analysing historical images and texts I will show that the original layout of the older western part of Highgate Cemetery can be understood as a semantic matrix that through its pathways and sceneries creates a cnarrative> outline, which could be taken up and individually shaped when perambulating the terrain. In other words, the landscape and architecture of St James' cemetery set a basic semantic framework that, physically, affectively and intellectually experienced, enabled and guided the visitor to conceive his or her own stories.

Since a cemetery is less a closed and finished entity than, for example, a book or a painting but is an object of constant change through natural growth and decay, seasonal differences as well as through the continual addition of individual monuments, it cannot be my aim to discover one exclusive meaning of the landscape. ${ }^{11}$ Instead, I will address the following questions to the original $19^{\text {th }}$ century design of Highgate: What did the designers of Highgate do to stimulate favourable imaginations in the visitors' minds? What kind of semantic fields did they address when constructing different objects and sceneries? To what extent did the overall design of the cemetery provide a basic interpretative guideline for the sensations it sought to provoke? I will try to show that the general semantic plot underlying the cemetery's layout has a hierarchical and normative structure that, nevertheless, enabled the visitors to imagine death and afterlife in different ways.

10 See Foucault 1984, 6.

11 For a critique of interpretations that tend to overstress the parallels between gardens and other media like painting and literature see Hunt 2006. 


\section{Landscape Cemeteries as Sites of Imagination}

That the sight of a landscape is able to stimulate the viewer's imagination is an idea as old as the concept of landscape in Europe itself. Francesco Petrarca's (Petrarch's) famous Mont Ventoux-Epistle (c. 1350) is often cited as the first testimony of an aesthetic appreciation of a natural landscape by an early modern individual. The panorama from the top of Mont Ventoux not only induced the poet to give a neat topographical description, but the landscape also inspired him to meditate on ancient myths and history, the human capacity of sight, his own biography, and finally (turning to Augustine's Confessions) higher religious truths. ${ }^{12}$

Much later the landscape's capacity to exalt human imagination was theoretically outlined by Joseph Addison in a series of essays On the Pleasures of the Imagination (1712) and became an essential concept in the English Garden movement. Addison understood imagination (or 〈fancy〉) as a mental faculty that was «furnished with ideas» via the exterior senses, especially sight. ${ }^{13}$ It was a capacity of social relevance not only indispensable for poets but for the gentleman as well, who should cultivate a polite imagination> in order to profit from the effects it had on morality and health. ${ }^{14}$ The strong linkage between landscape and imagination is based in part on the traditional association of the literary arts with gardening that goes back to antiquity and that was also stressed by Addison in his comparison of different garden designs with poetic genres: «I think there are as many Kinds of Gardening as of Poetry: Your makers of parterres and Flower Gardens, are Epigrammatists and Sonneteers in this art, Contrivers of Bowers and Grottos and cascades are romance writers.» ${ }^{15}$ The equation of the composition of gardens and texts was adopted by writers and garden enthusiasts like William Shenstone who wished his garden «The Leasowes» (created 1743-1763) to «resemble an epick or dramatick poem.» ${ }^{16}$ To promote this kind of perception Shenstone indicated the optimal viewpoints of his garden by the placement of benches and combined the vistas with inscriptions and poems given on boards. ${ }^{17}$ In his Essai sur les jardins (1774)

12 On Petrarch's ‘peak experience» see Michalsky 2006.

13 Addison 1803 (1712), 72.

14 Addsion 1803 (1712), 73.

15 See Addison's fictitious reader's letter «On the Pleasures of the Imagination», Addison, 1806 (1712), 23-24. On the parallels between writing and gardening see also Grillner, 2006; Tabarasi, 2007, 162, 369-393.

16 Shenstone 1764, 128.

17 See Verschragen 2000, 79. 
the French theorist Claude-Henri Watelet drew a more structural parallel between literature and gardening when he equated the pattern of pathways in a park with the exposition of a romance; ${ }^{18}$ as if the avenues, paths and trails were a succession of phrases and sentences that were read walking the terrain.

In fact, the layout of walks and visual axes was one of the major concerns in the English garden movement because it was regarded as having a strong effect on imagination. ${ }^{19}$ Addison had opposed the geometrically outlined baroque garden, which enabled the visitor to discern the entire extent of a terrain at first sight, as giving little nourishment to imagination and opted, instead, for the "wide Fields of Nature, [where the sight] is fed with an infinite variety of Images.» ${ }^{20}$ It was a common idea that the number of images produced by a garden could be increased by the use of undulating paths and winding vistas. In the view of the British politician and garden theorist Thomas Whately, for example, the unregularly curved footpath was not only more graceful than a straight one, it also enriched the sensual experience of a garden by offering a plurality of possible views. ${ }^{21}$ Another statement for the inspiring power of undulating designs was made by the architect Edward Kemp in How to layout a garden (1850): «A wavy line is $[\ldots]$ indefinite and awakens the idea of infinity with its exhaustless stores for the imagination and it is of the commonest occurrence in natural scenery.»22

These ideas, developed in regard to the landscape garden, were also deemed valid for the layout of the new cemeteries. ${ }^{23}$ In light of a long tradition of placing sepulchral monuments in natural ambiences that goes back to Arcadian myths, ${ }^{24}$ advocates of the British cemetery movement emphasised that a landscape garden setting could engender manifold imaginations by offering interrelated sensations of nature, architecture, tombs and epitaphs that blend in with the visitor's remembrance of the dead. Very meaningful in this sense is a passage from John Strang's Necrop-

18 See Watelet $1774,24$.

19 See Dauss 2012.

20 Addsion 1803 (1712), 73; see Baridon 2006, 69.

21 Whately 1770, 17-18; On the importance of imagination in Whately's concept see Wimmer 1989, 170-171.

22 Kemp 1858 (1850), 133.

23 Nevertheless, prominent garden designers like John Claudius Loudon disliked cemeteries that completely followed the model of a park or spleasure ground. See Loudon 1843, 19-20.

24 On the tradition of burials in parks and gardens see Linden-Ward 2007, 29-80. 
olis Glasguensis (1831), in which the later chamberlain of Glasgow stresses the positive effects a picturesque cemetery can have on one's imagination:

If the corrupters of Christianity still attempt to terrify rather than to console humanity, and if superstition still exercises her fatal spell, does it not become the duty of every wellwisher to his species to pour into the tomb the light of religion and philosophy [...] The decoration of the cemetery is a mean peculiarly calculated to produce these effects. Beneath the shade of a spreading tree, amid the fragrance of the balmy flower, surrounded on every hand with the noble works of art, the imagination is robbed of its gloomy horrors the wildest fancy is freed from its debasing fears. Adorn the sepulchre, and the frightful visions which visit the midnight pillow will disappear; and if a detestation for annihilation, mingled with the fondest affection for those who are departed, should lead men still to believe that the dead hold communion with the living, the delightful illusions which will result from this state of things, will form a pleasing contrast to the vile superstitions that preceded them. Let the fancied voice of a father pierce, in the silence of the night, the ear of the son, who lives unmindful of his parent's early counsels, or let the shade of a warning mother appear in the lunar ray, to the thoughtless and giddy eye of her who threatens to sacrifice her beauty and her virtue at the shrine of flattery. These fancies the children of a pious sorrow, will neither debase the human mind, nor check the generous impulses of the human heart. ${ }^{25}$

Strang contrasts the horrible superstitions induced by inappropriate and distasteful burial grounds (implicitly referring to the situation of the urban graveyards) with the beneficial imaginations that arise from a conjunction of the mourner's loving remembrance of the departed with a synergy of pleasurable sensations offered by the garden cemetery. In the latter case even the illusion of a communication with the dead would promote morality and Christian belief.

William Justyne, the author of the first guide to Highgate cemetery, likewise stresses imagination as one of its most worthwhile effects. In his first lines he wonders: «Is it imagination which makes us feel an inspiration pure and celestial while we walk noiselessly from grave to grave?» 26 Justyne uses a romantic topos describing how the distance to the city and the access to nature free his imagination: «Poetry revels in the bosom of

25 Strang 1831, 61-62.

26 Justyne $1865,8$. 
Nature, and is nourished by the broad study of her laws, but it withers in the cold and selfish atmosphere of a great city.» ${ }^{27}$ In this little book it is oftentimes the fusion of different sensations of artful monuments, their inscriptions, the flora and fauna, a natural shade or flash of light with the author's learning that triggers his poetic expression. At the moment, for example, when Justyne was reading the inscription of the delicate tomb of Emily Zoete a butterfly settled on one of the dwarf granite columns, and after being zoologically identified as «papilio io» (peacock butterfly), the author feels forcibly recalled to cite some verses of a poem, in which the state of pupation is paralleled with the grave and the following eternal freedom of the soul. ${ }^{28}$

\section{Highgate Cemetery as Semantic Framework}

The ground map of the western part of Highgate Cemetery (fig. 1) shows that David Ramsey, the planning landscape architect, gave most of the primary routes a sinuous shape. The effects of enhancing a landscape's grace and variety assigned to these forms have already been mentioned and were acknowledged also by the contemporary press. In November 1838, even before Highgate was officially opened, the weekly journal The Mirror of Literature, Amusement, and Instruction praised how the serpentine walks intriguingly bind the plantations and monuments and produce the illusion that the relatively small cemetery ground is three times its extent. ${ }^{29}$ Compared to the models proposed by other contemporary cemetery architects, Ramsey chose a middle way avoiding the extremes of a strict rectangular layout, suggested most prominently by John Claudius Loudon to be the most appropriate and solemn solution, ${ }^{30}$ or of very flowery and artificial designs like the one advertised by a successful American cemetery company (fig. 2). In doing so Ramsey complied with the ideal of the landscape garden in which paths should correspond to the natural terrain and not appear as a product of deliberate artistry. In fact, the rising gradient of the ground on which Highgate Cemetery was built gave a natural explanation for the need of winding walks.

27 Justyne 1865, 12.

28 See Justyne 1865, 23-24.

29 The Mirror [..., ] No. 32/3, 1838, 290.

30 Loudon 1843, 19. 


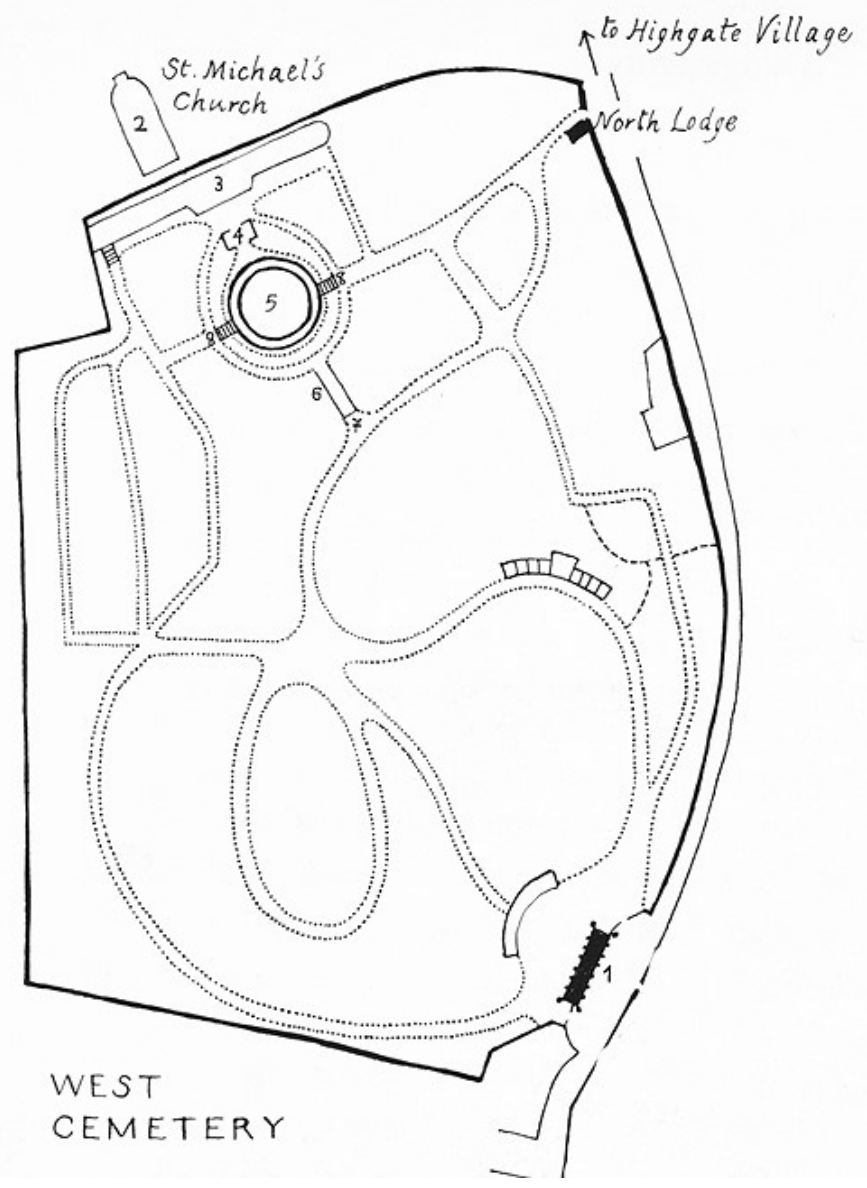

Fig. 1: Ground Map of Highgate Cemetery Western part (Image: Alberto Saviello 2017).

That St James' was laid out on a hillside can be regarded as one of its fundamental characteristics. The main entrance of the cemetery, a neo-Tudorstyle building (fig. 1, no. 1; fig. 3), which contained two separate chapels for the funeral services of Anglicans and Dissenters, was erected at Swain's lane at the lower southern end of the grounds. Thus, every visitor had to climb the sloping terrain at least up to the point of the grave she or he intended to see but oftentimes also up to the hilltop where two other features rewarded the visitor for the sstrenuous〉 walk: the neo-gothic Church 
of St Michael's that had been built shortly before the cemetery by Lewis Vulliamy in 1832 (fig. 1, no. 2; fig. 4) and the so called terrace catacombs whose asphalted platform offered a vista over the neighbouring districts and the city of London (fig. 1, no. 3; fig. 5). The view of both, church and panorama, almost at the topographical peak of Highgate hill formed the turning point of the visit and thus a kind of climax. While the Anglican building of St Michael's opened a semantic field of relatively restricted associations, the connotations of the panorama were less concrete.

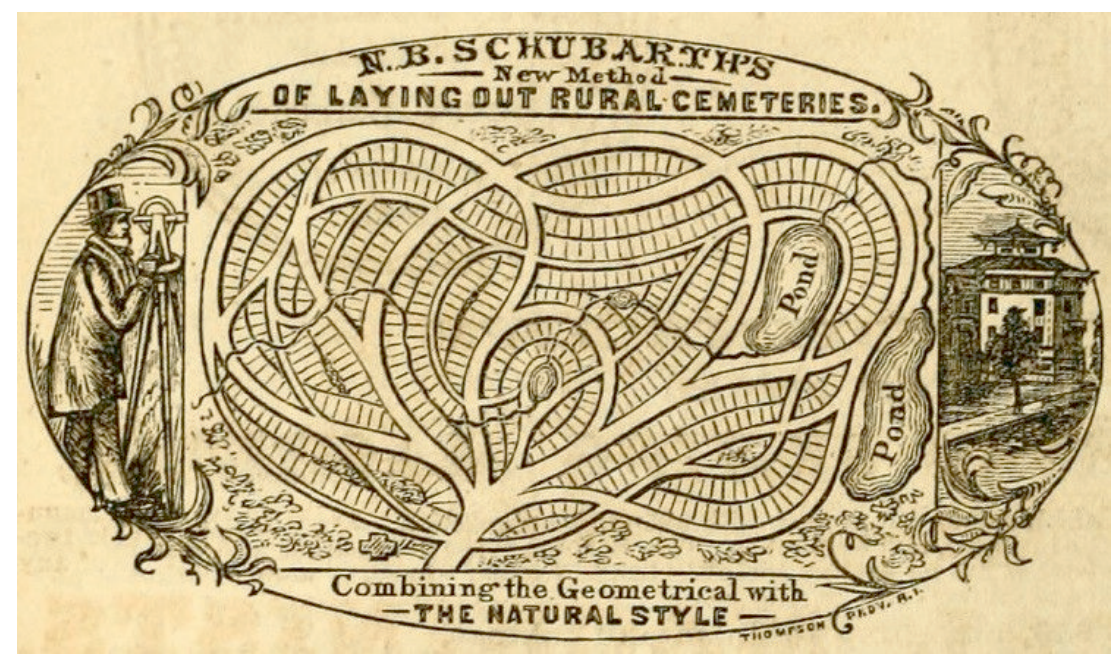

Fig. 2: Plan for a Rural Cemetery by Niles B. Schubarth of Rhode Island, United States, wood engraving, 1861 (Image: Wiki Commons). ${ }^{31}$

31 https://commons.wikimedia.org/wiki/File:Schubarth_cemetery.jpg (accessed August 19, 2020). 

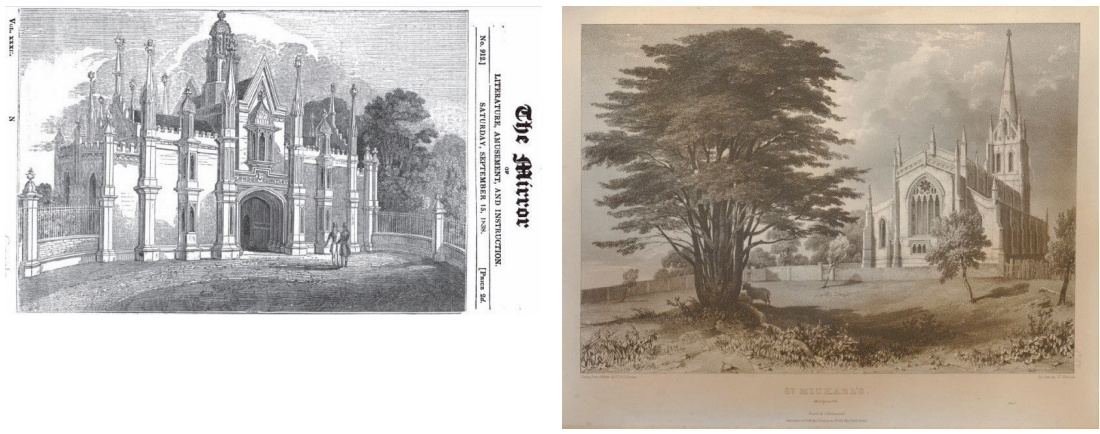

Fig. 3: Entrance to the London Cemetery, Highgate, wood engraving, in: The Mirror [...],15.9.1838, title page.

Fig. 4: H. A. Gillman, St Michael's Church Highgate, 1832, lithographed by W. L. Walton.

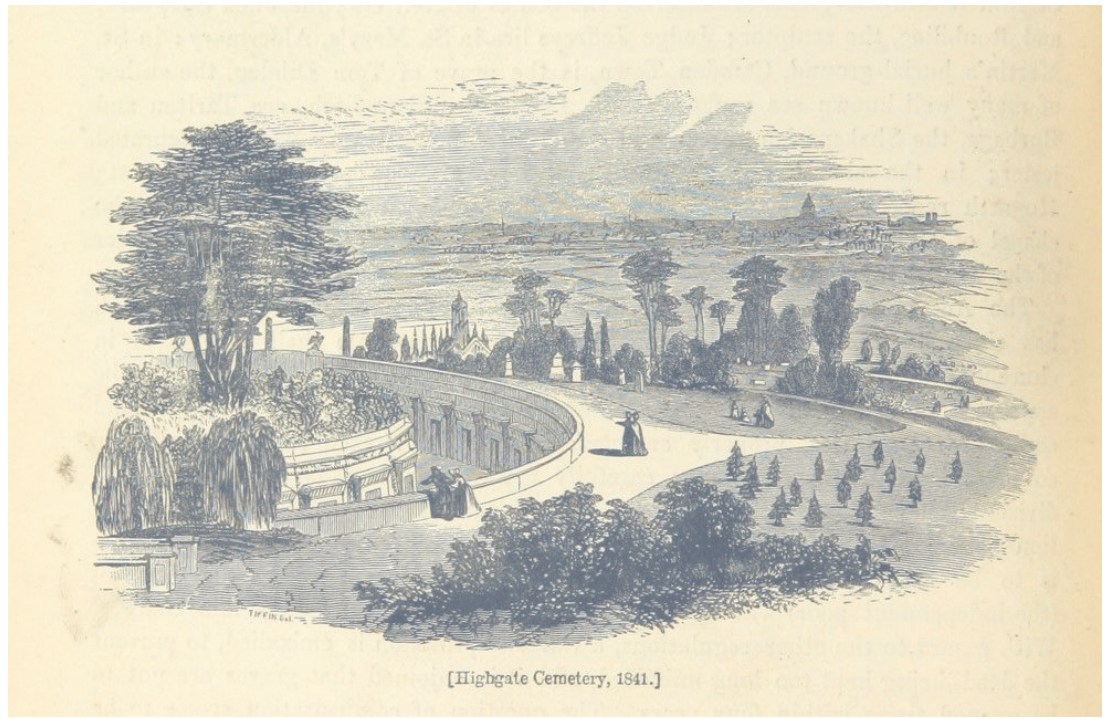

Fig. 5: Highgate Cemetery, 1841 [with a View of London], wood engraving. 


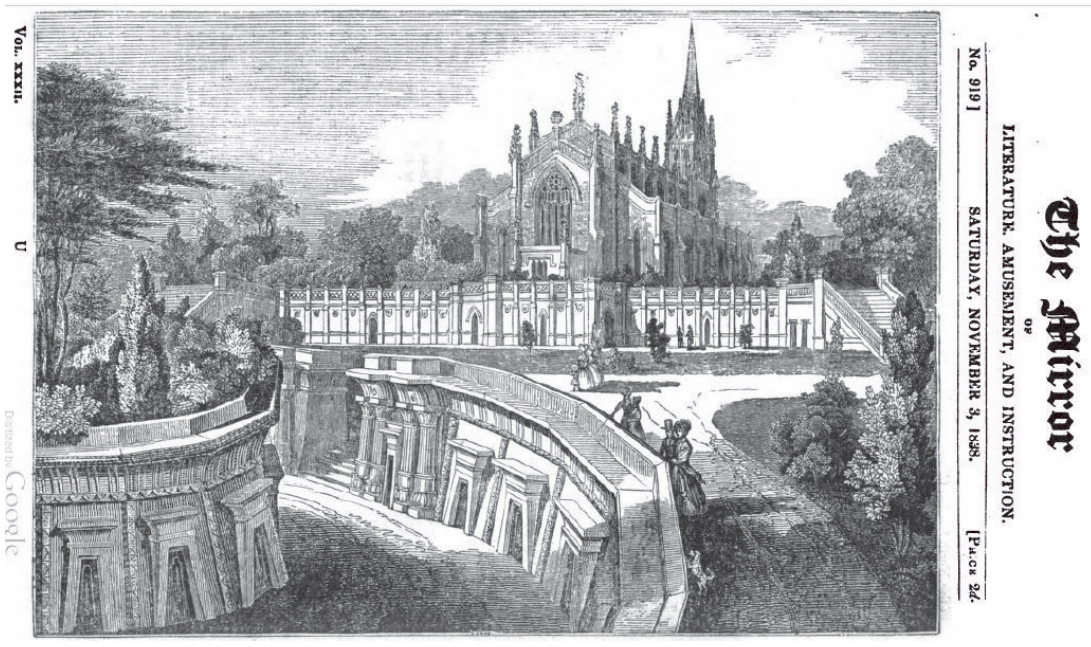

Fig. 6: I. Dodd, North London Cemetery, Highgate, [The Terrace Catacombs and St Michael's], wood engraving, in: The Mirror [...], No. 32/3, 1838, title page.

Although St Michael's was not institutionally affiliated to the cemetery and stands outside of its terrain, in an etching from The Mirror of 1838 (fig. 6) the catacombs and the staircases on both sides leading to the roof terrace almost appear as the architectural basis, functioning as the crypt of the church. ${ }^{32}$ This impression is reinforced by the dense sequence of pilaster strips structuring the catacombs' front wall and its elongated portals with gothic arches that match very well with the church's buttresses and lancet windows. Even the church's rectangular protruding apse corresponds to the catacomb's median risalit, the middle entrance jutting out from the facade. It seems that through this architectural affiliation Geary wanted to profit from the church's vicinity and to get a share in its splendour and religious significance. ${ }^{33}$ The importance of the adjacent church for the cemetery has been emphasised also by contemporary reports. The Penny Maga-

32 The Mirror [...], No. 32/3, 1838, 291: «A glance at the engraving [fig. 6] will show how excellently Mr. Geary has availed himself of the contiguity of this beautiful structure, by forming the terrace and Gothic catacombs immediately beneath it; and thus the church becomes one of the grandest ornaments of the cemetery.»

33 Sometimes, in case of funerals for prominent persons St Michael's was used instead of the small chapels at the cemetery's entrance for the funeral service. See The Gentleman's Magazine, February 1848, 204. 
zine and John H. Lloyd's The History, Topography and Antiquities of Highgate state that to the cemetery's "great advantage» the church can be seen from almost every part of its ground. ${ }^{34}$ What this advantage exactly meant, was not clarified by the authors but it can be suggested that it was seen in the church's iconic as well as symbolic value, namely that it towered over the other important monuments of the cemetery as a symbol of Christianity (fig. 7). ${ }^{35}$ Furthermore, taking into account that every visit started by passing through an entrance that was a chapel in neo-gothic style, both endpoints of the cemetery's landscape were unmistakably marked by Christian architecture stylistically referencing English tradition.

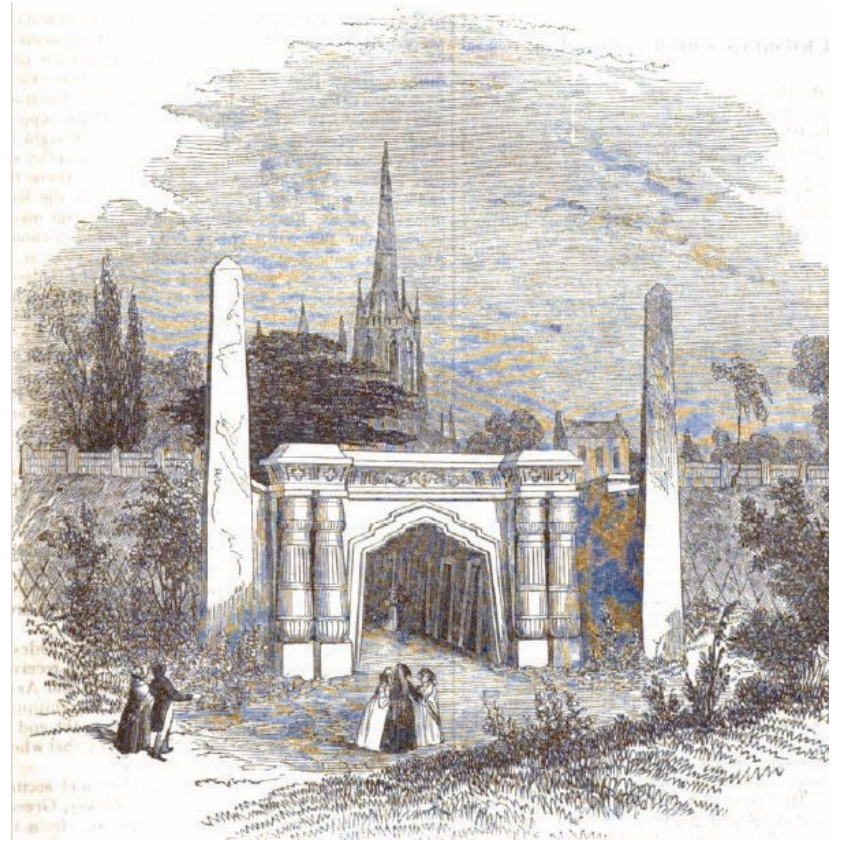

Fig. 7: Charles Knight, Entrance to the Catacombs of the Cemetery at Highgate, wood engraving, in: The Penny Magazine, 21.12.1839, title page.

34 The Penny Magazine, 21.12.1839, 489; Lloyd, 1888, 494-495.

35 In this sense also Loudon recommended that the chapel of a cemetery should «be placed in a central and conspicuous situation, so as, if possible, to be seen from all the prominent points of view along the roads and walks.» Loudon 1843, 19. 
Less distinct in its meaning but nevertheless important for the landscape's attractiveness was the airy view of the metropolis that could be enjoyed from the terrace catacombs (fig. 5). This scenic outpost was already popular among excursionists before the ground became a cemetery and it is lauded in almost every contemporary description of Highgate. For its function as a turning point of the cemetery's walk it seems important that it broadened the view after the visitors had been more focused on specific sepulchral monuments - representatives of individual human fates - or on single natural objects. It was believed that distant views had a pleasing and relieving effect on the mind. The poet Thomas Miller, for example, wrote in his description of a visit to Highgate that in overlooking the open country and the trees and flowers that cover the graves he felt accompanied by «those who now sleep their long sleep»" and that the panorama "cause[s] us to contemplate death kindly.» ${ }^{36}$ The effect that the view had on Miller complies with contemporary philosophical and literary interpretations in which wide vistas where linked to the ideas of infinity and the sublime; sometimes the distant horizon was even understood to be an actual attribute of the divine. ${ }^{37}$ Nevertheless, a landscape's panorama was much more open for individual imaginations than specific signs or symbols. Accordingly, Joseph Addison understood «a spacious horizon as an image of liberty», 38 liberty> in the context of politics as well as of imagination. The view from Highgate hill could even be endowed with allegorical meaning, as in John Galsworthy's first volume of The Forsyte-Saga from 1906, when the silhouette of London turns into a personification of mourning at the burial of dear aunt Ann:

From that high and sacred field, where thousands of the upper middle class lay in their last sleep, the eyes of the Forsytes travelled down across the flocks of graves. There-spreading to the distance, lay London, with no sun over it, mourning the loss of its daughter, mourning with this family, so dear, the loss of her who was mother and guardian. A hundred thousand spires and houses, blurred in the great grey web

36 Miller 1852, 275.

37 On the meaning of distant vistas in the English landscape garden see LindenWard, 2007 (1989), 144-145.

Addison 1803 (1712), 77: «Such wide and undetermined prospects are as pleasing to the fancy, as the speculations of eternity or infinitude are to the understanding.»

38 Addison 1803 (1712), 77. What Addison understood in a political sense coincides with individual freedom and liberty of imagination. 
of property, lay there like prostrate worshippers before the grave of this, the oldest Forsyte of them all. ${ }^{39}$

The integration of the panorama into the story does not point to a religious or spiritual meaning like a description of St Michael's may have done at this point. But the mourning city is meant to aggrandize the importance of Ann Forsyte as exponent of a specific historic mentality, a person with whom a part of Victorian England was gone and a whole era would come to an end.

That the space of a cemetery cannot be regarded as being homogenous in the values ascribed to it can already be learned from the sophisticated price list for the burial spots. They ranged from $£ 65 \mathrm{~S}$ for the interment of an adult in the eastern part of the terrain (probably referring to the dissenter's area), to $£ 1010 \mathrm{~S}$ in the centre, $£ 14$ for a single coffin in the terrace catacombs, $£ 18$ in the Egyptian Avenue and up to $£ 20$ in the circle of the Cedar of Lebanon catacombs. ${ }^{40}$ Even aside from pure economic data other historical cemeteries show, too, that the more prominent burial plots at the centre and preferably at crossroads were more sought after than less frequented areas. ${ }^{41}$ By far the most expensive spot at Highgate was not even listed in the official charts. In 1876 the newspaper baron Julius Beer paid $£ 800$ for a piece of ground to build a beautiful mausoleum for his daughter Ada who had died at the tender age of eight years (fig. 1, no. 4). The location he chose can be described as the most conspicuous individual plot in the whole cemetery. It lies just above the Circle catacombs and in the cemetery's main axis running along the Egyptian Avenue, traversing the Cedar of Lebanon and the centre of the terrace catacombs.

As already mentioned the catacombs of the Egyptian Avenue and those of the Circle of Lebanon were even more expensive than the terrace catacombs. The circular trench around an old magnificent Cedar of Lebanon (fig. 1, no. 5; fig. 6), a tree that already formed part of the estate when it still belonged to the Ashurst family, was constructed excavating the earth around it. The portals to the catacomb chambers in this artificial underground were designed by Geary in 1839 in an Egyptianising style. The straight Egyptian Avenue (fig. 1, no. 6), which leads to the circle, and its magnificent gate with Egyptian pilasters, flanking obelisks and a flying serpent in the middle of its frieze (fig. 1, no. 7; fig. 8) were added three years later by James Bunstone Bunning (1802-1863), who became Geary's suc-

39 Galsworthy 2001, 79-80.

40 See Cauch 1840, 63-64.

41 See Dorgerloh 2015, 94. 
cessor as surveyor of the LCC in 1839 . Finally, in 1870 probably due to great demand another 16 chambers with portals in a classical style were built along the outer wall of the trench surrounding the Cedar.

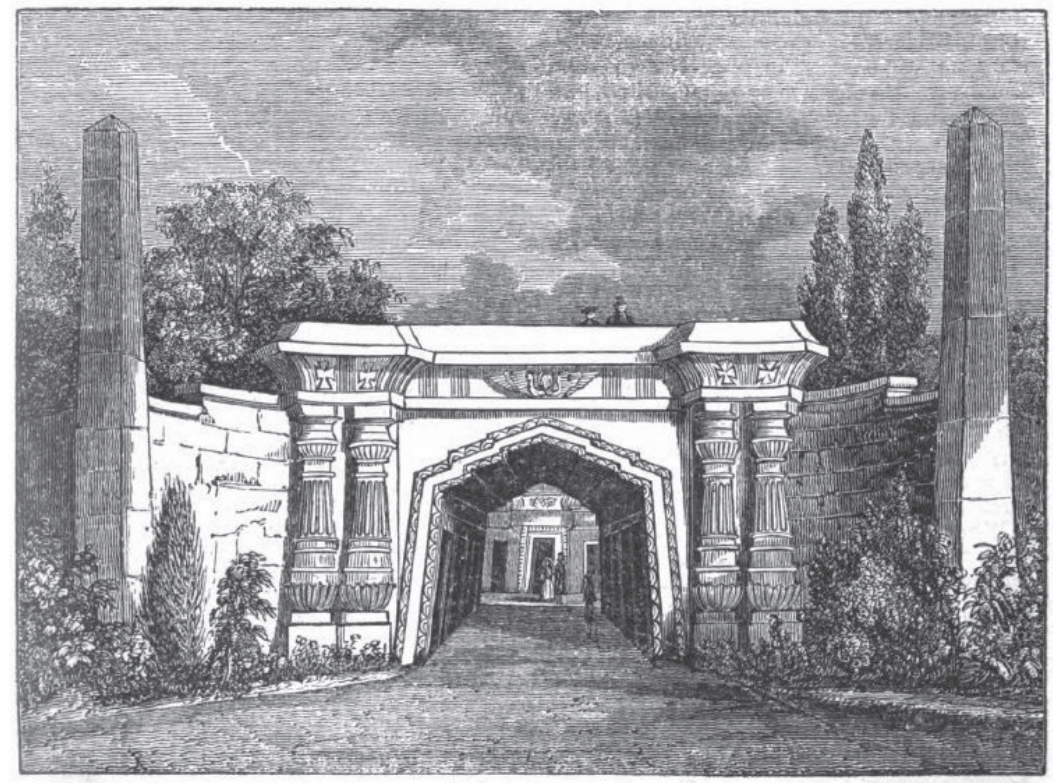

(THE EGYPTIAN AVENUB.)

Fig. 8: The Egyptian Avenue, wood engraving, in: The Mirror [...], 3.11.1838, 292.

The architects' choice of neo-Egyptian monuments was fashionable and innovative. In England the neo-Egyptian style had become increasingly popular around the beginning of the $19^{\text {th }}$ century, when the English gained military access to the land of the Nile and tomb raiders like Giovanni Battista Belzoni shipped Egyptian monuments and artefacts to London. While a range of individual sepulchres had previously been built in the neo-Egyptian style at other places, Highgate represented the first time that this style was applied to monuments constructed by a cemetery management company itself. ${ }^{42}$

The connotations of the Egyptian style were manifold. First of all, this style had been associated with sepulchres since antiquity. Already ancient

42 See Curl 1994, 178, 196-200. 
European authors knew that the pyramids were the burial sites of the Pharaohs. In Roman antiquity and again in Renaissance times Egyptian forms had been used for funerary monuments. In modernity, the Egyptian style was regarded as heavy and grave, giving an impression of timelessness and safety; and the antiquity of the Egyptian monuments underlined their suitability to preserve memory for eternity. ${ }^{43}$ Corresponding to the concept of an architecture parlante or «appropriate architecture», in the $19^{\text {th }}$ century the Egyptian style was applied to public buildings like cemetery gates and prisons - places which are designed to safely keep their residents inside - or to structures like bridges and railway stations that should convey strength and durability. ${ }^{44}$ From an intellectual and historical point of view, ancient Egypt was regarded as the «cradle of science and art, of philosophy, of science, and of legislation.» ${ }^{45}$ Thus, it was applied to libraries and courts of justice. However, it could also symbolise secret and hermetic knowledge especially when it was referred to in esoteric contexts. ${ }^{46}$

That the Egyptian portal at Highgate and the subterranean avenue actually recalled ancient burial cults as well as a kind of esotericism can be seen from some contemporary descriptions. The Mirror notes that the gate's «solemn grandeur» and «gloomy appearance» carries «the imagination to the sepulchral temples at Thebes described by Belzoni.» ${ }^{47}$ Entering «the awful silence of this cold, stony death-palace» Justyne suggested that «we might almost fancy ourselves treading through the mysterious corridors of an Egyptian temple» and Lloyd had the impression that the underground avenue «lead[s] into the very bosom of the hill.» ${ }^{48}$ In his analysis of Egyptian monuments in $18^{\text {th }}$ century landscape gardens, Jean-Marcel Humbert stresses their function to create «esoteric garden pathways allowing one to wander simultaneously in the material world and in the world of ideas.» ${ }^{49}$ Especially, in the context of Freemasonry, Egyptian garden objects and figural elements formed an «initiatory journey, or at least an esoteric experi-

43 See Carrot 1978, 103.

44 See Curl 1994, 180.

45 See Strang 1831, 6.

46 See Carrott 1978, 109, 133.

47 The Mirror [...], No. 32/3, 1883, 290.

48 Justyne 1865, 33; Lloyd 1888, 494.

49 Humbert 2006. On neo-Egyptian style in Freemasonry see also Curl 1994, 134136. 
ence», a «passage from darkness to light, the ultimate test before access to the domain of Knowledge and Wisdom.» ${ }^{50}$

Besides the impression of gravity and duration appropriate for cemetery architecture, it seems that constructing the Egyptian catacombs Geary and Bunning also deliberately aimed at a mystifying or even initiatory effect. Interesting in this regard is the junction of the straight Egyptian Avenue with the circular path around the Cedar of Lebanon that leads to an affiliation of the evocation of ancient Egypt with a natural monument. It is perhaps not by chance that such a connection can already be found in the Old Testament (Ezekiel 31:2-3), in which the magnificent Cedar of Lebanon is compared to the Assyrian Empire. In the parable that was meant as a warning to the Pharaoh of Egypt the Cedar, which became arrogant growing so tall that it «set its top among the clouds» (Ezek 31:10-12, English Standard Version), was ordered by God to be felled. Furthermore, in Victorian England the Cedar was regarded as the sacred tree of the Jews and even a seat of gods in Indian cults. ${ }^{51}$ Thus, both the tree and the Egyptian architecture could hint at ancient cultures and allude to the Old Testament, epitomizing in their antiquity and exoticism the idea of unknown hermetic and natural wisdom. In the Victorian era "Tree-worship», which was often combined with ritual circumambulation, was considered to be one of the oldest forms of religion. ${ }^{52}$ The architectural layout at Highgate, which made it possible for visitors to circle the Cedar, whose trunk and shadowing branches emerge even more stunningly and magnificent when seen from underground, lends it the character of a ritual or even a sacred object. Circumambulation was and is part of rituals in different religions - described by Eliade as corresponding to an archaic concept of a sacred, cyclic time. ${ }^{53}$ It is often connected with the idea of transposing profane into sacred time and opening-up access to the mystical centre. Correspondingly, also in $19^{\text {th }}$ century British popular belief it was a method to connect with the otherworld.54 The Egyptian Avenue and the Circle of Lebanon combined to constitute a dense setting of features to incite mystical, unorthodox and even pagan imaginations. What would Geary and Bunning have said if they knew that the Egyptian part of the cemetery would become fa-

50 Humbert 2006, 199, 208.

51 On the cedar see for example The Evangelical Register, March 1838, 95-96.

52 The Family friend, Midsummer 1864, 125-130.

53 See Eliade 1959, 16-62.

54 Menefee 1985. 
mous as a setting for ghost stories and horror films in the following centuries? 55

Already contemporary authors were «very doubtful whether the Egyptian style is the most appropriate for a Christian burial-place.» ${ }^{56}$ Loudon uttered this criticism because the Egyptian monuments evoked a religion that he considered «the most degraded and revolting paganism which ever existed.» ${ }^{57}$ Instead, he was of the opinion that cemetery architecture should remind visitors of Christian salvation, a purpose for which he regarded the Gothic style as much more suitable. Similarly, Augustus Welby Pugin, who argued that architectural styles had different moral values, contested the Egyptian revival. ${ }^{58}$ In his eyes, the use of neo-Egyptian style for cemetery buildings and decorations produced the "grossest absurdities.» ${ }^{59}$

It would have been problematic for the LCC if its cemetery buildings had been regarded by a majority of public voices to be pagan-like or unfitting for Christian burial. An important means of avoiding such a verdict was surely that the Egyptian monuments formed only a part, and definitely not the climax, of the cemetery's «narration». The darkness and concentration felt when stepping through the Egyptian portal and «into the very bosom of the hill», being surrounded by human remains in the underground avenue and circumambulating the roots of the Cedar of Lebanon, can be seen as a dramaturgical passage to increase the effect of the following scenery of the airy panorama of the terrace catacombs and the lofty spires of St Michael's. Entering the Egyptian avenue and the circle, the visitors had the choice to simply follow the path that without making any progress "conducts again to the entrance», like Lloyd somewhat disappointedly wrote, or they could elevates themselves taking one of the two opposing staircases (fig. 1, no. 8) that standing in an orthogonal axis to the Egyptian Avenue led away from the underground to another, now wider circling path on the upper level in front of the gothic terrace catacombs.

Thus, it was not only the frames of the gothic buildings at the endpoints of the cemetery's visit that assured a Christian interpretation of the landscape. Also the ascending terrain can be read, especially in relation to the sequence of the sceneries, as evoking the idea of a (mental) progress that develops from mystery and darkness in the Egyptian underground to

55 Huckvale 2012, 112-113. See also the contribution by Anna-Katherina Hoepflinger in this volume.

56 Loudon 1837, 16.

57 Loudon 1837, 16.

58 Curl 1994, 91, 181, 183.

59 Pugin 1895, 12. 
the brighter prospects of a wide panorama attached to a ritual place of Christianity. The implicit hierarchy of the cemetery's monuments can also be felt by looking at the engraving the Penny Magazine chose to present Highgate and in which the tower of St Michael's seems to watch over the Egyptian portal and the Cedar (fig 7). And again visitors well-versed in the Old Testament could even quote Ezekiel's parable linking the Cedar to the Pharaoh when leaving the underground level: when the haughty Cedar was felled, «all the peoples of the earth have gone away from its shadow and left it» (Ezek 31:12, English Standard Variation) - The Jewish-Christian God destroyed the magnificent ‘world-trees in order to overcome polytheism and lead the people to the light.

\section{Imagined Roots: Conclusion}

It was not only the natural features and winding paths of Highgate Cemetery that were meant to stimulate the visitors' imagination, it was also the variety of artistic styles applied to the architecture that opened different semantic fields and could sometimes evoke even seemingly conflicting associations. The contemporaneous use of neo-Gothic and neo-Egyptian architecture was highly eclectic and it is consistent with Foucault's definition of a heterotopos: it juxtaposes spaces - an Egytian «temple and a Christian church - that are incompatible in the everyday world. ${ }^{60}$ But this confrontation was not meant to put the different architectural objects on an equal footing. Instead it was supposed to create a dialectical tension in which the Egyptian was linked to darkness, concentration and cyclical movement and the Gothic to light, liberty and progress. At first sight, the structure of the rising terrain as well as the change from darkness to light enforced by the architectural setting both imply a superior status of the Gothic elements. This would correspond to the arguments uttered in the contemporary «Battle of Styles», in which the Gothic was advertised as belonging to the recent era of an already enlightened English civilisation, while (ancient) Egypt was seen as foreign, unchristian and overcome. ${ }^{61}$

But why were the burial plots in the Egyptian part so attractive to contemporary buyers? This question cannot be explained by the fashionable

60 Foucault 1984, 6.

61 On the idea of the «Battle of styles» a term that was coined in 1860 and that ascribed more or less distinct symbolic values to the different styles see Gowans in Eastlake 1975 (1872), X. 
quality of the Egyptian style alone. Jan Assmann showed that especially during the English enlightenment ancient Egypt became a model for the construction of what he calls a "religio duplex.» ${ }^{62}$ In this sense the contrast between the dark, esoteric, veiled Egyptian mystics and the light, exoteric, revealed Christian religion would form a dualism that merely describes two sides of the same coin: while outwardly overridden and superseded by Christianity, the ancient cult and its secret lore remain a still active (natural) force that even informs the invisible roots of the visibly practiced Christian religion. Such an elitist thinking (elitist because the secret was only accessible to a small group of initiates) could have been appealing for some of the upper Bourgeoisie customers of Highgate.

Perhaps of even greater importance, however, is that the nexus of Christianity with an ancient wisdom has a unifying power: if the religions and denominations in Victorian society are grounded on a common (now buried and invisible) lore their actual differences would appear to be accidental and even negligible. Other than the graveyards at the parish churches, the new cemeteries were built as burial sites for adherents of different religious nominations as well as for disbelievers. While the neo-gothic elements set a normative framework that ostentatiously demonstrates the superiority of the Christian faith, the Egyptian Avenue and the Cedar of Lebanon effect a more intimate and private way of dealing with death. Literally underneath the normative structure, they allude to an ancient religion that was alien to all believers (and infidels) in Victorian England, but that conveys the idea that all concepts of afterlife grow from the same «natural root.

\section{Bibliography}

Addison, Joseph, 1803 (1712), On the Pleasures of the Imagination [The Spectator, 411-421], in: The British Classics. Volume the tenth. Containing the sixth volume of the Spectator, London: C. Wittingham, 71-128.

Addison, Joseph, 1806 (1712), [Fictitious reader's letter regarding «On the Pleasures of the Imagination»], [The Spectator 477, September 6, 1712], in: The Spectator a corrected edition [...] in eight Volumes, Vol. VII, London: Bye and Law, 21-26.

Arnold, Catharine, 2006, Necropolis. London and Its Dead, London: Pocket Books.

62 See Assmann 2014. 
Assmann, Jan, 2014, Religio Duplex: How the Enlightenment Reinvented Egyptian Religion, New York: John Wiley \& Sons.

Baridon, Michel, 2006, Understanding Nature and the Aesthetics of the Landscape Garden, in: Calder (ed.), 2006.

Calder, Martin (ed.), 2006, Experiencing the Garden in the Eighteenth Century, Oxford: Lang.

Carrott, Richard G., 1978, The Egyptian Revival. Its Sources, Monuments, and Meaning, 1808-1858. Berkeley: University of California Press.

Cauch, John, 1840, The Funeral Guide; or, A Correct List of All Burial Fees [...], [London]: Mile End.

Clements, Paul, 2017, Highgate Cemetery Heterotopia. A Creative Counterpublic Space, Space and Culture, 20/4, 470-484.

Collison, George, 1840, Containing a Concise History of the Modes of Interment Practised by the Ancients [...], London: Longman, Orme, Brown, Green and Longmans.

Curl, James S., 1972, The Victorian Celebration of Death, Detroit: Partridge.

Curl, James S., 1994, Egyptomania. The Egyptian Revival. A Recurring Theme in the History of Taste, Manchester: Manchester University Press.

Dauss, Markus, 2012, «The undulating line» versus «line and compass». Mediale und semiotische Aspekte der Linienästhetik in der Theorie des Landschaftsgartens, in: Faietti, Marzia/Wolf, Gerhard (eds.), Linea II. Giochi, metamorfosi, seduzioni della linea, Firenze: Guinti, 178-191.

Dorgerloh, Annette, 2015, Von der Todesfurcht zum Trost in der Natur. Grundlagen für die Entwicklung von Gartengräbern im aufgeklärten Zeitalter, in: Dorgerloh, Annette/Niedermeier, Michael/Becker, Marcus (eds.), Grab und Memoria im frühen Landschaftsgarten, Paderborn: Fink, 89-116.

Eastlake, Charles L., 1975 (1872), A History of the Gothic Revival. With an Introduction by Alan Gowans, [Watkins Glen, N.Y.]: American Life Foundation.

Eliade, Mircea, 1959, Cosmos and History. The Myth of the Eternal Return, trans. Willard R. Trask, New York: Harper Torchbooks.

Etlin, Richard A., 1984, Père Lachaise and the Garden Cemetery, Journal of Garden History, 4/3, 211-222.

Foucault, Michel, 1984 (1967), Of Other Spaces. Utopias and Heterotopias, trans. Jay Miskowiec, Architecture, Mouvement, Continuité, 5, 46-49, retrieved from http://web.mit.edu/allanmc/www/foucault1.pdf (accessed June 11, 2017) (Different paging, 1-9).

Galsworhty, John, 2001 (1906), The Forsyte Saga, Vol. 1: The Man of Property, In Chancery and to Let, Hertfordshire: Wordsworth Editions.

Grillner, Katja, 2006, Experience as Imagined. Writing the Eighteenth-century Landscape Garden, in: Calder (ed.), 2006, 37-64.

Huckvale, David, 2012, Ancient Egypt in the Popular Imagination: Building a Fantasy in Film, Literature, Music and Art, North Carolina: McFarland \& Company. 
Humbert, Jean-Marcel, 2006, Egypt in the Eighteenth-century Garden. Decline or Revival of the Initiatory Journey, in: Calder (ed.), 2006, 189-212.

Hunt, John D., 2006, Stourhead Revisited \& the Pursuit of Meaning in Gardens, Studies in the History of Gardens \& Designed Landscapes, 26, 328-341.

Justyne, William, 1865, Guide to Highgate Cemetery, London: K. Moore.

Kemp, Edward, 1858 (1850), How to Lay Out a Garden. Intended as a General Guide In Choosing, Forming or Improving an Estate, London: Bradbury and Evans, $2^{\text {nd }}$ ed.

Linden-Ward, Blanche M. G., 2007 (1989), Silent City on a Hill. Picturesque Landscapes of Memory and Boston's Mount Auburn Cemetery, Amherst, Mass.: University of Massachustts Press.

Lloyd, John H., 1888, The History, Topography and Antiquities of Highgate, in the County of Middlesex, Highgate: n.p.

Loudon, John C., 1837, Loudon's Architectural Magazine. And Journal of Improvement in Architecture, Building, and Furnishing, and in the Various Arts and Trades Connected, Vol. 4, London: Longman, Rees, Orme, Brown, Green \& Longman.

Loudon, John C., 1843, On the Laying Out, Planting, and Managing of Cemeteries; and on the Improvement of Churchyards, London: Longman, Brown, Green and Longmans.

Menefee, Samuel P., 1985, Circling as an Entrance to the Otherworld, Folklore, 96/1, 3-20.

Michalsky, Tanja, 2006, «Limes ille Galliarum et Hispaniae, Pirenaeus vertex, inde non cernitur» - Zum Verständnis von Land und Landschaft in verschiedenen Medien des italienischen Spätmittelalters, in: Spieß, Karl-Heinz (ed.), Landschaften im Mittelalter, Stuttgart: Steiner, 237-266.

Miller, Thomas, [1852], Picturesque Sketches of London. Past and Present, London: Office of the National Illustrated Library.

Penny, Nicholas B., 1974, The Commercial Garden Necropolis of the Early Nineteenth Century and Its Critics, Garden History, 2/3, 61-76.

Pugin, Augustus W. N., 1843, An Apology for the Revival of Christian Architecture in England, Edinburgh: John Weale.

Rugg, Julie, 1997, The Origins and Progress of Cemetery Establishment in Britain, in: Jupp, Peter C./Hwarth, Glenny (eds.), The Changing Face of Death. Historical Accounts of Death and Disposal, London: Macmillan, 105-199.

Shenstone, William, 1764, Unconnected thoughts on Gardening, in: The Works, in Verse and Prose of William Shenstone Esq., Vol . II, London: n.p., 125-147.

Strang, John, 1831, Necropolis Glasguensis; With Observations on Ancient and Modern Tombs and Sepulture, Glasgow: Atkinson and Company.

Tabarasi, Ana-Stanca, 2007, Der Landschaftsgarten als Lebensmodell. Zur Symbolik der «Gartenrevolution» in Europa, Würzburg: Königshausen \& Neumann.

The Evangelical Register. A Magazine for Promoting the Spread of the Gospel, [monthly journal], [London]: J. M. Robeson. 
The Family friend, [1849-1921], [monthly journal], London: S. W. Partridge \& Co. The Gentleman's Magazine, New Series, [1731-1907], [monthly journal], London: n.p.

The Mirror of Literature, Amusement, and Instruction, [1822-1850], London: J. Limbird

The Penny Magazine of the Society for the Diffusion of Useful Knowledge, [18321845], London: Charles Knight \& Co.

Verschragen, Jeroen L., 2000, Die stummen Führer der Spaziergänger. Über die Wege im Landschaftsgarten, Frankfurt a.M.: Lang.

Watelet, Claude-Henri, 1774, Essai sur les jardins, Paris: Imprimerie de Prault.

Whately, Thomas, 1770, Observations on Modern Gardening, London: n.p., $2^{\text {nd }}$ ed. Wimmer, Clemens A., 1989, Geschichte der Gartentheorie, Darmstadt: Wiss. Buchgesellschaft. 
